UDK 811.163.42’373

Izvorni znanstveni rad Rukopis primljen 27. III. 2018. Prihvaćen za tisak 23. V. 2018.

Jurica Budja

Institut za hrvatski jezik i jezikoslovlje

Ulica Republike Austrije 16, HR-10000 Zagreb

jbudja@ihjj.hr

\title{
NAPOMENE O LEKSEMU SPLAV
}

Da bi se očistio put do etimologije imenice splav, autor se dotiče nekoliko njezinih aspekata: pitanja zemljopisnoga razmještaja, pitanja semantike i pitanja roda starih potvrda. Pretresa se i njezina tvorba.

Baveći se u okviru projekta „Baza hrvatskih morfoloških dubleta” Instituta za hrvatski jezik i jezikoslovlje dvorodnim imenicama, ukazala se je potreba rasvijetliti povijest imenice splav i, ako je moguće, iznaći prvanji njezin rod, dakle u stvari razriješiti njezinu etimologiju. Zato smo se koncentrirali na:

- prostorni razmještaj povijesnih potvrda, kako hrvatskih, tako srpskih

- znamenovanje leksema u povijesnim potvrdama, kako hrvatskim, tako srpskim

- rod leksema u povijesnim potvrdama, kako hrvatskim, tako srpskim.

Zatim smo imenicu splav problematizirali s gledišta tvorbe riječi. Spoznaje smo na kraju saželi.

Ne zadržavamo se na stvarima koje spadaju na etimološke priručnike: da je splav izvedena iz korijena plov-, da u tom i tom slavenskom jeziku jest neka formalno ili semantički slična riječ i sl. Ovdje provodimo dubinsko bušenje na jednom nalazištu da bismo apstrakciji udahnuli životnost i da bismo raspršili eventualnu općenitost (često površnost) koja je u naravi svih priručnika, tako i etimoloških. Drugim riječima, ispitujemo mogućnosti unutrnje rekonstrukcije. 


\section{Prostorni razmještaj povijesnih potvrda}

\section{I.1. Leksem splav u hrvatskom}

Korpus potvrda razdjeljujemo na dva bloka: 1 . blok potvrda iz pretpreporodnoga perioda, 2. blok potvrda iz poslijepreporodnoga perioda. S ilirskim preporodom stvoren je temelj općehrvatskoga standardnoga jezika, a svrha je standardnoga jezika da se dotrgnu pokrajinske osobitosti u korist umjetne ujednačenosti. Zato je standard(izira)ni jezik od slabe pomoći za jezičnopovijesna iziskivanja, iako stanovite pokrajinske jezične vlastitosti žive u njemu još neko vrijeme.

Za gornji vremenski međaš korpusa uzeli smo godište 1872. Razlog je što u djelu Na splavih A. Tomića, koje toga godišta bī objavljeno u časopisu Neven, prvo ukazanje imenice splav, ono u natpisu, prati podrubnica: „Splav: Floss”. Pisac djela ili urednik časopisa još tada je dakle ćutio potrebu širemu općinstvu protumačiti riječ splav, što ukazuje da je u općenom jeziku bila nova.

Imena „Osijek” i „Rijeka” su službena, nenarodna imena za hrvatske gradove Osik i Riku (Sv. Vida). Jer su službena, morali smo se njima služiti.

\section{a) Pretpreporodno doba}

- Kruna obderxavaiucsiu stanie apostolsko. [...]. Xivot svetog Ivana od Nepomuka, […] (1759. F. A. Eitzenberger. Pešta) A. J. Knezovića, slavonskoga Bunjevca rođena u Osijeku, koji je do 1759. život proveo po različitim mjestima Kaločke nadbiskupije (Kaloča, Gara, Baja, Varadinski Šanac) (http://hbl. lzmk.hr/clanak.aspx?id=9497):

- Reče: „Zlatni jest vik, sad se za zlatom grabi, / jer zlatom se ljubav i pokornost vabi. / Teško je voziti sprama vitru splav, / teže je ugibati od bogastva narav. (A. J. Knezović, Život svetog Ivana od Nepomuka, 146)

- Rječnik („Slavonisches Wörterbuch”) gramatike Neue Einleitung zur slavonischen Sprache (1789. I. M. Divald. Osijek) M. Lanosovića, Slavonca rođena u Orubici kraj Nove Gradiške:

- Der Floß, ova splav, -i. (M. Lanosović, Neue Einleitung zur slavonischen Sprache, 138)

- Ricsoslovnik illiricskoga, italianskoga i nimacskoga jezika (1803. J. Kurzböck. Beč) J. Voltiggija, rođenjem Istranina:

- Splav, -vi f. Piatta, zatta. Floß m. (J. Voltiggi, Ričoslovnik iliričkoga, italijanskoga i nimačkoga jezika, 500) 
- Prijevod Svetoga Pisma (prije 1822. Izdano: 1831. Kraljevska mudroskupština madžarska. Budim) M. P. Katančića, Slavonca rođena u Valpovu, koji je život proveo u Slavoniji (Osijek), po različitim mjestima u Mađarskoj (od toga najdulje, i to zadnjih trideset godišta života, u Pešti i Budimu) i u Hrvatskoj (Zagreb) (Matić 1940: LX-LXXVI):

- Sluge moji položit će $\mathrm{i}_{\mathrm{h}}$ (drva cedrova $i$ čempresova) s Libana $\mathrm{k}$ moru, a ja ću $i_{h}$ složit u splavim na moru tija do mista koje mi objavio budeš, i stovarit ću $i_{h}$ ondi, a ti ćeš $i_{h}$ odnest; i dodat ćeš potribita meni, da se dade ${ }_{h}$ rana kući mojoj. (M. P. Katančić, Sveto pismo Starog zakona, II, 428 [1 Kr 5, 9]) < lat. ...et ego componam ea in ratibus in mari usque ad locum...

- Mi ćemo pak sići drva od Libana koliko za potribu uzimaš, i složit ćemo $\mathrm{i}_{\mathrm{h}}$ na splavim po moru u Joppe; tvoje pak bude prinest $\mathrm{i}_{\mathrm{h}} \mathrm{u}$ Jerusalem. (M. P. Katančić, Sveto pismo Starog zakona, II, 737. [2 Ljet 2, 16]) < lat. ...et applicabimus ea ratibus per mare in Joppe...

- Ali da ne bi tašta bila mudrosti tvoje dila, zato još i malom drvu uzdaju ljudi duše svoje, i prišav more na splavi, oslobodiše se; [...]. (M. P. Katančić, Sveto pismo Starog zakona, III, 644. [Mudr 14, 5]) < lat. ...et transeuntes mare per ratem liberati sunt...

- Grammatik der illyrischen Sprache (1833. Kraljevska mudroskupština madžarska. Pešta) I. A. Brlića, Slavonca iz Broda:

- Das Floß, splav. (I. A. Brlić, Grammatik der illyrischen Sprache, 315)

- Kerstovka (1835. J. Gyurián i M. Bagó. Budim. Prijevod-prepjev Christiade Dubrovčanina Dž. Palmotića) spomenutoga I. A. Brlića:

- Tako kobna zvizda ona koju / za znamenje vičnji Bog objavi, / ili vojski prepravnoj u boju, / il' na moru kojoj punoj splavi, // kano jasan plamen po zracima / strelovita ona s neba srne, / a nevoljnim ljudma umrlima / srdce čezne od stra $\mathrm{h}$ i trne. (I. A. Brlić, Krstovka, III, 52, str. 43) < dubr. hrv. Tako kobna zviezda koju / za zlamen'je Višnji objavi / ili spravnoj vojsci u boju / ili u moru punoj plavi...

- Zaklopjene usrid tvrde splavi, / koji onda ne biše u gri ${ }_{h} \mathrm{u}$, / malo ljudī od ljudske naravi / sa ranjeni samo tudi bi $\mathrm{h}_{\mathrm{h}}$. (I. A. Brlić, Krstovka, III, 545, str. 59) < dubr. hrv. ...sred zaklopne tvrde plavi, / ne bivši se našli u griehu, / mali ljudske od naravi / sahranjeni samo bjehu.

- [...]; // kako cio Izrael brez splavi / među prike sad uniđe vale, / i slobodno put međvodni prävī / na žuđene krajeve i žale; // [...]. (I. A. Brlić, Krstovka, VII, 249, str. 144) < dubr. hrv. ...vas Izrael kō bez plavi / među prieke side vale... 
- Zaklopljenoj pak samo u splavi, / da sve sime ljudsko ne pogine, / malo ljudī vičnji Bog ostavi, / i to brez sveg gri ${ }_{\mathrm{h}}$ i krivine. (I. A. Brlić, Krstovka, XIII, 297, str. 289) < dubr. hrv. U zaklopnoj samo plavi, / da sve ljudstvo ne pogine, / male ljudi Bog ostavi, / a bez grieha i krivine.

- I moj mili rođak Filip tada / zazvan, skoči onaj čas iz splavi, / i pogubu ni$\mathrm{mi}_{\mathrm{h}}$ ribni $_{\mathrm{h}}$ stadā / i zabave sve svoje ostavi. (I. A. Brlić, Krstovka, XIV, 70, str. $305)<$ dubr. hrv. ...zazvan taj čas, skoči s plavi...

- Ja ga vidi očima ovima, / i drugovi sa mnome svi ini, / red davati strašnim valovima, / uzdu stavljati nji ${ }_{h}$ ovoj vrlini; // i gdi ōle ustavljuje vitre / preoštrome svojom zapovidi, / da nji ${ }_{h}$ ova sila splavi ne tre / $\mathrm{i}$ da polje morsko da ne jedi. (I. A. Brlić, Krstovka, XIV, 439, str. 316) < dubr. hrv. ...da njih sila plavi ne tre, / morsko polje da ne jedi.

- U to vrime Petar s svojom družbom / vozaše se u prebrzoj splavi / po moru, gdi sa novima zidom / Tiberijad grad dično se slavi. (I. A. Brlić, Krstovka, XXIII, 122, str. 516) < dubr. hrv. Petar s družbom u toj vrime / primetaše s brzom plavi / more...

- A ostala družba sva za njime / u punoj se vozeći tud splavi, / zajedno s plinom obilnime / na žuđeni kraj nogu postavi. (I. A. Brlić, Krstovka, XXIII, 194, str. 518$)<$ dubr. hrv. Družba ostala sva za njime / u punoj se vozeć plavi...

- Splav, -i; brod [,,Splav i brod"], lađa, galija, korablja. Das Schif. Navis. (I. A. Brlić, Krstovka, Znamenovanje njeki ${ }_{h}$ sumračni $_{\mathrm{h}}$, svakom neobični ${ }_{\mathrm{h}}$ i riđega upotribljenja ričī, 610b)

- Henriada (prije 1841. Rukopis, izdan u: Građa za povijest književnosti hrvatske, 25. 167-211. Prijevod La Henriade Voltairea) F. Štrehea, užega Hrvata rođena u Varaždinu:

- Lepe tu ovčice vode (Englezi), / hambari tu puni, novce su sim zbrali, / na suhom su strašni, na morju pak kralji, / splav njih prezmožni vsa morja je pokril, / sreču ter blago po svetu njim odkril. (F. Štrehe, Henrijada, 335) < franc. Leur flotte impérieuse asservissant Neptune...

- Nut, ti neprijatelji jesu sad vaši, / i moji su, kē se nas nigdo naj plaši: / Filip, koj na me spravil prestrašen splav, / na me se z vojskum svūm nameril je prav, / i sad mi još z mrtveci svēmi zrak truje, / [...]. (F. Štrehe, Henrijada, 433) < franc. Contre moi l'un \& l'autre osérent s'élever: / l'un combattant en vain l'Anglois \& les orages; / fit voir à l'Océan sa fuite \& ses naufrages, / du sang de ses guerriers ce bord est encor teint... 
b) Poslijepreporodno doba

- Anonimni prijevod zakonskoga akta br. 184, natpisa Razpis ministarstva tèrgovine od 11. svibnja 1850, kojim se dostavlja do obćega znanja, da se austrianska carina na Labi rieci od česti ukida (1850., u: Sveobći dèržavozakonski i vladni list za Cesarevinu Austriansku, 1850., II. Carsko-kraljevska dvorska i državna štamparija. Beč):

- [...], dostojalo je nj. Veličanstvo previšnjom odlukom od 4. svibnja t. g. premilostivo odobriti da se austrijanska carina na Labi sasvim ukinuti ima za sve malo nižje ne naročito izuzete robe, koje se na Labi rieci između Melnika i saksonske granice razvoze na austrijanskih brodovih i splavih. (Anonim, Razpis ministarstva trgovine od 11. svibnja 1850., u: Sveobći državozakonski i vladni list za cesarevinu Austrijansku, 1850., II, 871)

- Atala (1856., u: Neven, V. Narodna tiskarnica dra Ljudevita Gaja. Zagreb. Prijevod Atala F. R. de Chateaubrianda) V. Vežića, Dalmatinca rođena u Selinama kraj Starigrada, koji je do 1856. živio u Zagrebu i Varaždinu:

- Kad nas je susrela koja rieka, ili smo ju preplovili na splavi ili preplivali. (V. Vežić, Atala, u: Neven, V, 35a) < franc. ...nous le passions sur un radeau ou à la nage.

- Pogled u Banat ljeta 1855. (1856., u: Neven, V. Narodna tiskarnica dra Ljudevita Gaja. Zagreb) pisca pseudonima Rodoljub Sriemac, što je pseudonim M. Stojanovića (Orešković 1978: 266), Slavonca rođena u Babinoj Gredi:

- U Lipi je vrlo znatna trgovina sa splavovi i drugom građom i drvi. (Rodoljub Sriemac, Pogled u Banat ljeta 1855., u: Neven, V, 114a)

- Grad Halič (1856., u: Neven, V. Narodna tiskarnica dra Ljudevita Gaja. Zagreb), crtica anonimna pisca:

- [...]; po modroj pučini tiho plove duge splavi; [...]. (Anonim, Grad Halič, u: Neven, $\mathrm{V}, 327 \mathrm{~b})$

- Dopisi o Italiji, II. (1858., u: Neven, VII. E. Rezza. Rijeka) pisca inicijalā A. T., što su inicijali A. Vebera poznatijega kao Tkalčević (Vidačić 1951: 57), (polu-)hrvatskoga Primorca rođena u Bakru:

- [...]; ali naše splavi plove ovdje mirno bez svake pogibelji: kopnom voze Kranjci bačve pune vina hrvatskoga, a niz rieku skaču kano vjeverice po praznih bačvah skupa svezanih, pa to su im splavi. (A. T., Dopisi o Italiji, II., u: Neven, VII, 519)

- Anonimni prijevod zakonskoga akta br. 24, natpisa Ugovor o brodarstvu dunavskom izmedju Austrije, Bavarske, Turske i Virtemberžke od 7. studeno- 
ga 1857. (1858., u: Zemaljsko-vladni list za kraljevine Hèrvatsku i Slavoniu, 1858., I. Narodna tiskarnica dr. Lj. Gaja. Zagreb):

- Čl anak XI. [...]. Brodovom sagrađenim tako da služe samo za jednu vožnju niz vodu ne treba patenta brodnoga, i smatrat će se u tom obziru kao splavi. [...]. Članak XXXV. [...]. Umjesto patenta propisanoga u članku XVI., treba da je vođa od splava proviđen patentom splavnim koji će po priklopljenom izgledu $D$. izdati nadležna vlast zemlje pobrježne. [...]. Splavi ne potrebuju patente po propisu članka XIV. Nego svaki vođa od splava ima oskrbljen biti pismi koja će posvjedočivati vlastnika ili pošiljatelja, a i izhodište i namjenu splava, i koja će isti vođa držan biti, kadgod se zahtievalo bude, pokazati vlasti brodarstvenoj. [...]. Članak XL. [...]. A i mostovi imat će, koliko moguće bržje, davati slobodan prolaz brodovom i splavom. [...]. Prilog C. (k članku XXIV) [...]. 6. Za neznatne prenose na kratak put, a tako i za robu koja se prenosi na splavih, dovoljan će biti umjesto pravoga otvorenoga pisma prost izkaz o tovaru. [...]. Prilog D. (k članku XXV) [...]. Pošto je vlastnik ovoga pisma N. N. . . ... iz . . . . . posvjedočio potrebita znanja i sposobnosti, bi mu dopušteno bez prigovora pod danom današnjim da upravljati može na Dunavu svaki splav drveni. lzza kako je zavjetovao od svoje strane da će splav koji je povjeren upravljanju njegovomu voditi sa svom pomnjom i opreznostju; [...]. (Anonim, Ugovor o brodarstvu dunavskom između Austrije, Bavarske, Turske i Virtemberžke od 7. studenoga 1857., u: Zemaljskovladni list za kraljevine Hrvatsku i Slavoniju, 1858., I, 116, 128, 130, 135, 137)

- Anonimni prijevod zakonskoga akta br. 26, natpisa Naredba ministarstva tèrgovine od 29. siečnja 1858. valjana za svekolike krunovine izim Krajine vojničke, o uvietih, pod kojimi će se podieljivati austrianske iskaznice za potočno brodarstvo ili splavarstvo po Dunavu (1858., u: Zemaljsko-vladni list za kraljevine Hèrvatsku i Slavoniu, 1858., I. Narodna tiskarnica dr. Lj. Gaja. Zagreb):

- Prigodom ove prijave imade 1. svaki pojedini poduzetnik brodarstva [...] naznačiti kakovom vrstom i kolikim brojem od brodovā ili kolikim brojem splavā namjerava on zanimati se brodarstvom ili splavarstvom. [...]. Svaki vođa od broda na vesla ili na jedra ili od splava na Dunavu ima bit oskrbljen redovitim patentom brodarskim ili splavarskim. [...]. lzpit ovaj obavljat će pripoznati majstori u brodarstvu ili patentovani jurve vođe od brodovā ili splavāa, [...]. Oni vođe od brodovā i splavā koji jurve izvršuju ovaj zanat na Dunavu, pak su $\mathrm{u}$ istom posvjedočili jurve praktičnu svoju izvrstnost, mogu se oprostiti od izpita, [...]. Pošto je vlastnik ovoga pisma N. N. . . . . iz N. . . . . posvjedočio potrebita znanja i sposobnosti, bi mu bez prigovora pod današnjim danom data dozvola da upravljati može na Dunavu svaki splav drveni. lza kako je zavjetovao 
od svoje strane da će splav koji je povjeren upravljanju njegovomu opravljati sa svom pomnjom i opreznostju; [...]. (Anonim, Naredba ministarstva trgovine od 29. siečnja 1858., u: Zemaljskovladni list za kraljevine Hrvatsku i Slavoniju, 1858., I, 142, 143, 144, 150)

- Što se vidi u banatskom selu? (1866., u: Bosiljak, II. D. Albrecht. Zagreb) M. Stojanovića, Slavonca rođena u Babinoj Gredi:

- Mi k prevozu, a prevozači uvlače kola i uvode desetak konjā lađarskih u splav ili skelu. (M. Stojanović, Što se vidi u banatskom selu?, u: Bosiljak, II, 103)

- Anonimni prijevod zakonskoga akta br. 103, natpisa Izprava o brodarstvu za uštja rieke Dunava, od 2. studenoga 1865. - Prilog A: Brodarstveni i redarstveni pravionik, valjan za dolnji Dunav i Prilog B: Tarifa pristojbah brodarstvenih, koje se pobirat imadu na uštjih dunavskih (1866., u: Sbornik zakonah $i$ naredabah valjanih za Hèrvatsku i Slavoniju, 1866. Narodna tiskarnica dra Lj. Gaja. Zagreb):

- Član. 25. Krmani od svakovrstnih splavā imadu se držati istih oprezā koji su propisani za brodove. Splavi, ploveći niz vodu u rukavcu Sulinskom, treba da gaze samo tako duboko, da na najplićih mjestih toga rukavca budu barem za jednu englezku stopu iznad dna; $[. .$.$] . Član. 52. Ako brod ili splav poradi$ magle bude prisiljen sustavit se na drugom mjestu, a ne na običnom sidrištu, imat će, ako je parobrod, zvonom zvoniti, a u protivnu slučaju vikati na ciev iliti glasilo. [...]. Član. 53. Splavi usidreni po noći treba da imadu luči propisane gorje u posljednjoj točki članka 47., [...]. Član. 55. Svaki kapetan ili gospodar od broda ili splava koji se nasuče iliti nasjedne u tieku Suline, držan je [...]. Član. 56. Parobrodi prolazeći mimo mjestā gdje je brod ili splav nasio ili potonuo ne smiju se služiti nego samo polovicom snage svoje. [...]. Član. 76. Za plovitbu niz vodu imadu svi trgovački brodovi imajući preko šestdeset bačavā, a tako i splavi svakovrstni, poslužit se povlađenim vodičem drugoga razreda. [...]. Član. 99. Svaki krman od splava koji zatečen bude da mu splav ploveći rukavom Sulinskim dublje gazi nego što je gori u trećoj točki čl. 25. propisano, past će pod kazan najmanju od deset, a najveću od petdeset dukatā. [...]. (Anonim, Izprava brodarstvena za ušća dunavska - Prilog A, u: Sbornik zakonā i naredabā valjanih za Hrvatsku i Slavoniju, 1866., 193, 201, 202, 208, 216)

- Član. 7. Splavi i splavštine koje u duljini stotinu, a u širini četrdeset englezkih stopā ne nadilaze i koje se tegle niz vodu kroz rukavac Sulinski, plaćaju pri izlasku iz ušća stalnu pristojbu od sto franakā. Daća iznosi tristo franakā za sve splave i splavštine koje rukavom Sulinskim niz vodu ne budu tegljene, i 
za one kojih duljina nadilazi sto, a širina četrdeset stopā englezkih. [...]. Č lan . 12. Jedrenjače od više nego šestdeset bačavā koje su plovile od Suline uz vodu, a tako i splavi i splavštine, plaćaju pri izlazu iz rieke za obvezatno provođenje niz vodu stalnu taksu, [...]. Član. 17. Svi brodovi, splavštine i splavi koji bi načinom ma kojim pokušali sasvim ili stranom uklonit se platežu stalnih pristojbā ustanovljenih ovom tarifom podvrženi su [...]. (Anonim, Izprava brodarstvena za ušća dunavska - Prilog $B$, u: Sbornik zakonā i naredabā valjanih za Hrvatsku i Slavoniju, 1866., 229, 231, 234)

- Tri pisma apokrifa (1869. Tiskarna oo. mehitarista. Beč) N. Koritića, što je pseudonim J. Miškatovića (Vidačić 1951: 31), Slavonca rođena u Cerniku:

- Sreća da se stvar ta prije raztepla nego sam iz Kranjske dao na splavih dopremiti za to potrebiti materijal. (N. Koritić, Tri pisma apokrifa, 8)

- Na splavih (1872., u: Vienac, IV. Dionička tiskara. Zagreb. Prijevod češkoga pisca O. Jendličke) pisca inicijalā Al. T. i pridjevka Požežanin, što su inicijali A. Tomića (Vidačić 1951: 56), Slavonca iz Požege:

- Na splavih. [...]. Ali slušaj - tamo daleko u šumi kao da se pjesma razlieže - približuje se sve većma i većma - oj! eno na površini rieke pomalja se već iz šumske sjene dug red splavi, a na njih veselo pjevajući splavari; [...]. - Gdje ćemo pritjerati k obali? - ozva se glas sa prednjih splavi. - Tamo dalje, da još danas prevalimo divju branu, - odvrati siedi splavar koji je sjedio na posljednjoj splavi, na svežnju vrbova pruća, [...]. Mislio sam si to, da ćemo stopram za divjom branom stati, - reče starji već splavar na prvoj splavi svomu mladomu sudrugu. [...]. Kamogod bi se ganuo Vaclav, morao bi biti s njim i Jakob; kad bi s gorā u dol plavili drva, oni bi bili uviek skupa na jednoj splavi, $-[\ldots]$. Vaclav pozdraviv ga muče, sjede kao negda na istu splav na kojoj je Jakob sjedio. [...]. Bura je grozno biesnila nam nad glavom, [...], a voda tekla tako brzo, da nam ne bijaše nikako možno zaustaviti splavi. [...]. Vaclav stajaše s Jakobom kao mi dva na prvoj splavi. [...]. Već leti prva splav sred zapjenjenih valova, [...]. Ali sad pozor, već se približujemo k divjoj brani, treba biti na oprezu da zadržimo splavi u glavnoj struji. [...]. Već splavi strujom lete nad divjom branom. [...]. Stari Tomaš stoji na zadnjoj splavi te sklopljenima rukama, suznim okom gleđe napred. - Pozor! - povikaše splavari na prvih splavih. Već je sletila prva splav po valovih dol, namah zatim druga, treća - i posljednja minula sretno pogibeljni slap. [...]. Jedni izašli na brieg da nalože vatru i skuhaju večeru, drugi pako legli na splavi da se po dnevnom naporu snom okriepe. (Al. T. Požežanin, $N a$ splavih, u: Vienac, IV, 198-198a-198b-199b-200a) < češ. ?. 
- Gojenje šumah s' navlastitim obzirom na Dalmaciju i Istru (1872. Braća Battara. Zadar) pisca K. Jovića, Dalmatinca iz ?:

- b) Izvažanje drvā po vodi. To se može činiti na sljedeće načine: [...], 3. na splavima i lađami. (K. Jović, Gojenje šumā s navlastitim obzirom na Dalmaciju i Istru, 116)

- Splavi (Zattera, Floss) zovu se jedna na drugu (u većoj ili manjoj množini) privezane grede iliti debla koja plivaju po vodi i provide se odzada sa odugačkima veslima, ili bolje da rečem kormilima. Takove splavi rabe se na ovećih riekā, kao n. p. na Dunavu, za odpremanje niz vodu. (K. Jović, Gojenje šumā s navlastitim obzirom na Dalmaciju i Istru, 120)

\section{Sinteza}

U dopreporodno doba leksem splav je posvjedočen kod peterih pisalaca. Četverica od njih su rođeni Slavonci (A. J. Knezović, M. Lanosović, M. P. Katančić, I. A. Brlić), četvrti je Istranin (J. Voltiggi). Dva od četiriju Slavonaca (A. J. Knezović, M. P. Katančić) dobar - bolji - dio života probaviše u Mađarskoj. Voltiggi je leksem mogao preuzeti iz djela kojega od pisaca što ih spominje $u$ uvodu rječnika, moguće od Lanosovića.

U okolopreporodno doba leksem splav je posvjedočen i kod pisca užega $\mathrm{Hr}$ vata Varaždinca F. Štrehea. Njegov prijevod Henrijade i prateće pisanje obiluju srpskim riječima, od onih koje danas i jur neko vrijeme uhu Hrvata djeluju domaće (npr. upoznati, predložiti, pojaviti se, udaljiti se, uveseliti, priroda, svojstvenost, izobilje) do onih za koje bi nevješt i dandanas rekao da nisu hrvatske (npr. istočnik, spisati, proiznašati). I splav će tako biti srbizam. Time se lasno tumači muški rod, a idiosinkratično znamenovanje (v. niže) je nedvojbeno posljedica semantičke reinterpretacije nedorazumljena novoga leksema.

U poslijepreporodno doba do godišta 1872. leksem splav je posvjedočen $\mathrm{s}$ jedne strane u četirima zakonskim tekstovima, brezimenim prijevodima s njemačkoga i francuskoga. S druge strane, kod sedmerih pisaca, od kojih su trojica Slavonci (M. Stojanović, J. Miškatović i A. Tomić), jedan po materi hrvatski Primorac (A. Veber Tkalčević), dvojica Dalmatinci (V. Vežić i K. Jović), a jedan anoniman.

Zakonski tekstovi su pjesma za sebe. Očito su pisani slijedeći principe Bečkoga književnoga dogovora (1850.), drugim riječima sa stanovitim udjelom nehrvatske štokavštine. Recimo, u zborniku zakonā kraljevstava Hrvatske i Slavonije Sveobći državozakonski i vladni list za cesarevinu Austrijansku, god. 1850., svezak II., u kojemu se nalazi jedan od zakonskih tekstova u kojem je 
leksem splav posvjedočen (s natpisom Razpis ministarstva trgovine od 11. svibnja 1850.), sustavno se na dnu svake stranice koja prethodi natpisnoj stranici zakonskoga teksta donosi manjim slovima bilješka o jeziku. Izmjenjuju se Croat. i Serb. Croat. dot. Serb. croat. Spomenuti tekst određen je kao Serb. Croat. Kako je u popisanim četirima zakonskim tekstovima leksem splav breziznimno muškoga roda, a leksem splav taj rod ima u srpskom jeziku dosljedno od najstarijih potvrda, u hrvatskom pak nikako, tako valja izvesti da je rod toga leksema u tekstovima te vrsti odstupak srpskomu jeziku. Moguće je da se je leksem splav u hrvatskim zakonskim tekstovima utvrdio baš posredstvom srpskoga jezika, nasljedujući jezik gotovih uzoraka zakonā države Srbije.

Pretpreporodne potvrde jednoglasno, zanemari li se Voltiggijeva rječnična, upućuju na sjeveroistok hrvatskoga jezičnoga prostora kao na mjesto gdje je leksem splav postao ili gdje je u hrvatski bio primljen. Poslijepreporodne potvrde to u najmanju ruku ne pobijaju - trojica pisaca koji se njime služe jesu sa sjeveroistoka hrvatskoga jezičnoga prostora (iz Slavonije), a trojica nisu.

Na hrvatskom jezičnom prostoru plovilo koje se načinja od svezanih drva denotiralo se je, koliko nam je poznato, još dvjema hrvatskim leksemima, plutva i povodnica, i dvjema posuđenicama, cataralčatara/čatra i sl. iz tal. i flos/fljos iz njem. Svi su prvi put posvjedočeni prije leksema splav.

\section{I.2. Leksem splav u susjednim jezicima}

Između hrvatskomu susjednih jezika leksem splav se nahodi u srpskom, a od druge polovice 19. st. i u slovenskom (za posljednje usp. rezultate upita na mrežnoj stranici Fran - Slovarji Inštituta za slovenski jezik Frana Ramovša ZRC SAZU: https://fran.si/iskanje?View=1\&Query=splav).

Spomenici srpskoga jezika 18. i prve polovice 19. st. lokalizirani su većinom na sjeveru srpskoga jezičnoga prostora, u južnoj Ugarskoj, čime je mogućnost proučivanja prostornoga razmještaja jako sužena. Činjenica da leksema splav ne poznaje standardni bugarski jezik (usp. rezultate na: ibl.bas.bg/rbe/ lang/bg/сплав/; bugarski leksem je sal) može sugerirati da on nije bio udomaćen ni na jugu ili jugoistoku srpskoga jezičnoga prostora.

Slovenski splav je očito posuđen iz srpskohrvatskoga; kako je muškoga roda, očito iz srpskoga dijela.

Srpske potvrde popisujemo do 1818. g., otkada je prva srpska navedena u Rječniku hrvatskoga ili srpskoga jezika JAZU (iz prvoga izdanja Srpskoga rječnika V. S. Karadžića): 
- Německïj i serbskïj slovarb na potrebu serbskagô naroda vъ kral. deržavahь (1791. J. Kurzböck. Beč) T. Avramovića, srijemskoga Srbljina rođena u Rumi:

- Floß (das), splav. Ein Floßbalken, balvan u splava. Floßholz, splavna drva. (T. Avramović, Njemeckij i serbskij slovar, 184b)

- Istorija raznyhъ slavenskihъ narodovъ, naipače Bolgarb, Horvatovъ $i$ Serbovъ, II (1794. S. Novaković. Beč) J. Rajića, srijemskoga Srbljina rođena u Karlovcima:

- Siji dva (Edče Beg i Fadčil Beg) obještalisja probovati ščastije pomoščiju Božijeju, priidoša na mjesto zovome Farančuk, gdje razorenyj njekotorij grad ležit, prjamo Zembennik Hisar vo Evropje sušča, tu mnogaja povjazaša drova i sdjelaša splav, i vstuplše na nj noštiju prepliša Helespont, i priidoša v predjeli Zembenika. [...]. Bez zakosnenija priugotovlennim ješče byvšim na to splavam, vsaždajet Sulejman 80 čelovjek izbrannago vojinstva svojego, kotoriji do posljednyja kapli krove obješčalisja stojati protiv vsjeh napadenij hristijanskih. $\S .13$. Vstupiša ubo Turki s voždem svojim na splavy tyja i prepliša noštiju Helespont. (J. Rajić, Istorija slavenskih narodov, II, 666)

- Životb i črezvyčajna priključenìja slavnago Angleza Robìnzona Krusse otъ İorka (1799. Kraljevska mudroskupština peštanska. Budim. Prijevod Des Robinson Crusoe Leben und gantz gemeine Begebenheiten L. F. Vischera) N. Lazarevića, kojega rodno mjesto nije poznato, a koji umrije u Budimu. U toj knjizi izbrojili smo imenicu 38 puta, na stranicama: 99-100 5x, 102, 102, 103, 103-104 5x, 105-106 6x, 108, 109, 109 3x, 110, 110, 114 2x, $1162 x, 140,145$, $145,147,202,475,520$ i 566.

- Rukovodstvo kъ francustěj grammatïcě (1805. Kraljevska mudroskupština peštanska. Budim) J. Vujića, bačkoga Srbljina rođena u Baji:

- Un radeau, splav. (J. Vujić, Rukovostvo k francuzstjej gramaticje, 261b)

- Mladyj Robìnzonъ (1810. Kraljevska mudroskupština peštanska. Budim. Prijevod Robinson der Jüngere J. H. Campea) rečenoga J. Vujića:

- Slavimir: Ja bi dobro znao šta bi sam učinio. // Otac: No, dakle šta? // Slavimir: Jedan splav. // Otac: Baš ovo isto pade najposle i našem Robinzonu na pamet! Jedan splav, pomisli on, moći će se ponajbrže načiniti. // Spasoje: A što je to splav? // Slavimir: Zar nisi vidio kad smo se pređe na jednoj ribarskoj lađici vozili da je tamo na Elbi kod Ribnjarskī vrata množestvo takovī splavova ležalo? // Spasoje: $\mathrm{A}_{\mathrm{h}}$ sad znam, to je jedna gromila balvana koji su jedan s drugim povezani tako da se lepo na njima može stojati i voziti, kako da 
bi kakva lađa bila. // Otac: Vesma dobro! Jedan takvi splav dakle ${ }_{\mathrm{h}}$ oteo je Robinzon načiniti i na njemu k velikoj lađi otplivati, pak iz nje toliko vešči izneti koliko bi su samo mogli. (J. Vujić, Mladi Robinzon, 296-297) < njem. Johannes. Ein Flößholz. Vater. Grade, eben dasselbe fiel unserm Robinson zulezt auch ein! Ein Flößholz, dacht'er, wird noch am geschwindesten gemacht werden können - Frizchen. Was ist denn das ein Flößholz? Johannes. ...eine Menge solcher Flößhölzer? ... Vater. Ganz recht! Ein solches Flößholz also wolte Robinson machen...

- Oni su priležno poslovali celi onaj dan, da su jošt onaj večer s splavom gotovi bili. (J. Vujić, Mladi Robinzon, 298) < njem. ...daß sie noch denselben Abend mit dem Flößholze zu Stande kamen.

- Oni nisu dakle ${ }_{\mathrm{h}}$ oteli ni jedno magnovenije oka propustiti, nego taki počeli su splav s brega dole valjati, da bi s vodom koja bi se s brega u more natrag slila moći ga bez mnogog truda na vodu baciti, kako što su blagopolučno svoj posao i soveršili bili. (J. Vujić, Mladi Robinzon, 299) < njem. Sie säumten also keinen Augenblik, das Flösholz vom Strande hinab zu rollen...

- On dakle pođe na splavu svud okolo galije za iskusiti dno mora, i ovde na veliku svoju žalost nađe da nije ni misliti na osvoboždenije njeno. (J. Vujić, Mladi Robinzon, 302) < njem. Er fuhr also auf dem Flößholze rund um das Schif herum...

- To je istina, Pero, ali je jarac njega potrebovao, a Robinzon bjaše vesma sožalitelen na sve životne tvari, i krome tog utrefilo se za njega neko malo mesto na splavu, zato uzede i njega sa sobom. (J. Vujić, Mladi Robinzon, 304) < njem. ...zumahl, da das Nothwendigste doch Raum auf seinem Flößholze hatte.

- Na ovaj sat morali su očekivati, jerbo inače s splavom teško bi mogli odavde poći. (J. Vujić, Mladi Robinzon, 305) < njem. ...weil sie sonst mit der Flöße schwerlich hätten fortkommen können.

- Sad veće bjaše vreme otliva ovde; obadva dakle siđoše se dole na splav, pak pustiše se na more, da bi s došedšim otlivom k bregu otploviti mogli. (J. Vujić, Mladi Robinzon, 306) < njem. ...beide stiegen also hinab zur Flösse und stiessen in See...

- Oni učiniše ot takovī (sjekirā $i$ drugoga oruđa) taki potrebu, pak otsekoše jednu malu katarku na njiov splav da bi mogli ubudušče jedan parus nametnuti moći, i onda ne više na vreme otliva morati čekati. (J. Vujić, Mladi Robinzon, 307) < njem. ...um einen kleinen Mastbaum für ihr Flößholz zu behauen...

- Oni dođoše opet blagopolučno, i prvo što su bili upazili bjaše ovo, da oni sve daske koje se na galiji na ${ }_{\mathrm{h}}$ ode na njiov splav natovare i dvostruki patos ot 
nji načine, da vešči koje bi sa sobom uzeli suvije negoli jučerašnje mogli izneti. (J. Vujić, Mladi Robinzon, 310) < njem....daß sie alle Bretter, die sie in dem Schiffe fanden, auf ihr Flößholz herab liessen...

- Budući da je vreme priliva jošt trajalo, to bjaše voda pri bregu tako plitka da prednja strana splava najedanput na pesak nasede, i zato daleko više podigla se bila neželi stražnja strana, koja jošt ot vode nosima bjaše. (J. Vujić, Mladi Robinzon, 314) < njem. ...daß das Vordertheil des Flößholzes auf einmahl auf den Sand rante...

- Brzo kako su bili došli na pol puta, podiže se tako strašna bura s gromovi, sevanjem, pucanjem i kišom pratima, da su talasi preko splava prelazili i na njemu stojeće vešči u bezdnu morsku zbacili. (J. Vujić, Mladi Robinzon, 320) < njem. ...daß die Wellen über das Flößholz wegrolten...

- Ali najposle ne mogaše slabo strojenije splava jarosti svirepī talasa dalše odoleti. Sveze s kojima su grede bile povezane raskidoše se, pak celi splav rastade se na komade. (J. Vujić, Mladi Robinzon, 320) < njem. ...das schwache Gebäude des Flößholzes...die ganze Flöße fiel aus einander.

- İstorìa trgovine otъ početka sveta do naši vremena (1816. Kraljevska mudroskupština peštanska. Budim) D. Isailovića, slavonskoga Srbljina rođena u Dalju:

- No Frankonija, Švarcvald, Nasauske zemlje, predeli na reki Mozelu i Saari ništa drugo nisu Holandezom nego javi magazini drvljani iz koji drva na veliki splavovī Rajnom k njemu plivaju. Splav takav sostoji se koje iz čamova, koje iz rastovī drva. [...]. Obično se oni kod Majnca sastavljaju iz manji splavova koji se tamo iz gornje Rajne i Majna skupljaju. (D. Isailović, Istorija trgovine, 244)

- Dosad je Šlezija od veliki svoji šuma mnogo drva za lađe i splavove Hamburgcem i Holandezom prodavala. (D. Isailović, Istorija trgovine, 277)

\section{Znamenovanje leksema splav u povijesnim potvrdama II.1. U hrvatskom}

U potvrdi A. J. Knezovića leksem splav denotira, čini se, 'lađa, brod'. Može se ovako razmišljati: da je Knezović mislio na riječno plovilo, vjetar bi se kao činitelj u njezinu gibanju morao isključiti, riječna bo se splav giblje pomoću riječnoga tijeka, niz vodu. Ostaje da je u pameti imao morsko (bolje rečeno, ne-riječno) plovilo, što bi odgovaralo proverbijalnoj naravi cijeloga 
odsječka. Ako već jest mislio na morsko plovilo, vjerojatnije je da je mislio na nekakovo generičko plovilo, sasvim moguće s jedrom, negoli na semantički dosta određenu 'splav'. Moglo bi se pomisliti i da voziti denotira usko 'veslati', ali ta je semantika karakteristična za primorske hrvatske krajeve, a u Slavoniji i Bačkoj taj glagol ima široko znamenovanje, kao u današnjem standardnom hrvatskom.

U potvrdi M. Lanosovića leksem splav je jednakovrijednica njemačkoga leksema $F l o \beta$, dakle denotira 'plutva, povodnica'.

U svim trima potvrdama M. P. Katančića leksem splav služi za prevesti latinski leksem ratis, dakle denotira 'plutva, povodnica'.

U rječniku J. Voltiggija leksem splav je jednakovrijednica talijanskih leksema piatta i zatta dot. njemačkoga Floß, dakle denotira 'plutva, povodnica'.

U potvrdi iz gramatike I. A. Brlića leksem splav je jednakovrijednica njemačkoga leksema $F l o \beta$, dakle denotira 'plutva, povodnica'.

U osmerima potvrdama iz Kristijade I. A. Brlića leksem splav služi za prevesti dubrovačkohrvatski leksem plav, dakle denotira 'lađa, brod'. Brlić poslavončuje dubrovački plav ne samo leksemom splav, već i leksemom lađa, a dvaput preuzimlje leksem plav iz izvirnika: I, 596: lađa; II, 69: lađa; XIV, 118: lađa; XIV, 453: plav; XIV, 501: plav; XV, 72: lađa; XVIII, 347: lađa; XVIII, 536: lađa; XXIII, 348: lađa.

U prvoj potvrdi iz Henrijade F. Štrehea leksem splav je jednakovrijednica francuskoga leksema flotte, dakle denotira 'flota', tj. množinu lađā. U drugoj potvrdi odgovarajuće francuske jednakovrijednice nije, ali se razumije da je to Španjolska armada, koju 1588. Englez potučē, dakle opet množina lađā. Moguće da je Štrehea na upotrebu jedninske imenice za množinski denotat naveo prefiks $s$-. Kakogod, teško može biti sumnje da je to znamenovanje imenice splav njegova izmišljotina.

U četirima zakonskim tekstovima leksem splav je jednakovrijednica njemačkoga leksema $F l o \beta$ dot. francuskoga radeau, dakle denotira 'plutva, povodnica'.

U potvrdi V. Vežića leksem splav služi za prevesti francuski leksem radeau, dakle denotira 'plutva, povodnica'.

U obadvjema potvrdama M. Stojanovića iz konteksta je bistro da leksem splav denotira 'plutva, povodnica'.

U potvrdi brezimena pisca crtice Grad Halič iz konteksta je bistro da leksem splav denotira 'plutva, povodnica'. 
U potvrdi J. Miškatovića iz konteksta je bistro da leksem splav denotira 'plutva, povodnica'.

U potvrdama A. Vebera iz konteksta je bistro da leksem splav denotira 'plutva, povodnica'.

U potvrdama A. Tomića leksem splav je, polag napomene u podrubnici, jednakovrijednica njemačkoga leksema Floß, dakle denotira 'plutva, povodnica'.

U potvrdi K. Jovića leksem splav je jednakovrijednica talijanskoga leksema zattera dot. njemačkoga $F l o \beta$, dakle denotira 'plutva, povodnica'.

Dakle, splav znamenuje 'plutva, povodnica' kod svih pisaca osim kod A. J. Knezovića i, djelomice, I. A. Brlića, ne računajući Štreheove potvrde. U svojem prijevodu Kristijade Brlić se imenicom splav (uz imenice lađa i plav) služi za prevesti Palmotićevu dubrovačku plav, koja, iz kontekstā se vidi, teško može znamenovati štogod kao 'plutva, povodnica', već redovito plovilo tipa lađe, veće ili manje. U pridatku prijevodu riječ splav glosira hrvatski kao „brod, lađa, galija, korablja”, njemački „das Schiff” i latinski „navis”, brišući svaku sumnju. Tu proturječi samomu sebi, jer u svojoj je gramatici imenicu splav glosirao njemačkom imenicom „der Floß”. I Knezovićev Sv. Ivan Nepomuk i Brlićeva Krstovka su umjetnička djela, i moguće je da je znamenovanje imenice splav u njima svijesno pomaknuto prama 'lađa', kao što se je u rimskoj književnosti imenica ratis 'splav' znala upotrebljivati u znamenovanju 'lađa'.

\section{II.2. U srpskom}

U potvrdi T. Avramovića leksem splav je jednakovrijednica njemačkoga leksema $F l o \beta$, dakle denotira 'plutva, povodnica'.

U potvrdi J. Rajića iz konteksta je bistro da leksem splav denotira 'plutva, povodnica'.

U potvrdama N. Lazarevića leksem splav dosljedno služi za prevesti njemački leksem $F l o \beta$, dakle denotira 'plutva, povodnica'

U potvrdi iz francuske gramatike J. Vujića leksem splav je jednakovrijednica francuskoga leksema radeau, dakle denotira 'plutva, povodnica'.

U potvrdama iz dječje robinzonijade J. Vujića leksem splav služi za prevesti njemačke lekseme Floß i Flößholz, dakle denotira 'plutva, povodnica'.

U potvrdama D. Isailovića iz konteksta je bistro da leksem splav denotira 'plutva, povodnica'.

Dakle, u srpskom splav znamenuje isključivo 'povodnica, plutva'. 


\section{Rod leksema splav u povijesnim potvrdama}

\section{III.1. U hrvatskom}

U potvrdi A. J. Knezovića neodrediva je roda.

U potvrdi M. Lanosovića ženskoga je roda.

U potvrdi J. Voltiggija ženskoga je roda.

U svim trima potvrdama M. P. Katančića ženskoga je roda.

U potvrdi iz ilirske gramatike I. A. Brlića neodrediva je roda.

U svim potvrdama iz Kristijade I. A. Brlića ženskoga je roda.

U obadvjema potvrdama F. Štrehea muškoga je roda.

U potvrdi V. Vežića ženskoga je roda.

U potvrdi iz prvoga teksta M. Stojanovića muškoga je roda, u potvrdi iz drugoga neodrediva.

U potvrdi brezimena pisca crtice Grad Halič ženskoga je roda.

U potvrdama A. Vebera Tkalčevića ženskoga je roda.

U potvrdi J. Miškatovića ženskoga je roda.

U potvrdama A. Tomića ženskoga je roda.

U potvrdama K. Jovića ženskoga je roda.

Potvrde iz četiriju zakonskih tekstova ne uzimljemo u obzir, kako smo više rastumačili. Valja opaziti da nom. mn. ima u njima kratku množinu, splavi, što u popisanim srpskim jezičnim spomenicima nije ovjereno.

Dakle, u hrvatskom je imenica od druge najstarije potvrde do 1872. u pravilu ženskoga roda. Muškoga je samo jednom, relativno kasno (M. Stojanović), isključujući Štreheove potvrde i potvrde iz zakonskih tekstova. U najstarijoj potvrdi rod je neodrediv.

\section{III.2. U srpskom}

U potvrdama T. Avramovića prvi put je neodrediva roda, drugi put je muškoga roda.

U potvrdama J. Rajića prvi put je muškoga roda, ostala dva puta neodrediva.

U potvrdama N. Lazarevića: str. 99-100: m. r. 4x, neodr. 1x; str. 102: neodr.; str. 102: neodr.; str. 103: m. r.; str. 103-104 m. r. 4x, neodr. 1x; str. 105-106: m. r. 6x; str. 108: m. r.; str. 109: m. r.; str. 109: m. r. 1x, neodr. 2x; str. 110: ne- 
odr., str. 110: m. r.; str. 114: m. r. 2x; str. 116 m. r. 2x; str. 140: m. r.; str. 145: m. r.; str. 145: m. r.; str. 147: m. r.; str. 202: m. r.; str. 475: m. r.; str. 520: m. r.; str. 566: m. r.

U potvrdi iz francuske gramatike J. Vujića je neodrediva roda.

U potvrdama iz dječje robinzonijade J. Vujića muškoga je roda, izim u trećoj potvrdi sa str. 296. i u onoj s str. 306., koje su neodrediva roda.

U svim četirima potvrdama D. Isailovića muškoga je roda.

Dakle, u srpskom je imenica splav od najstarije potvrde do 1818. dosljedno muškoga roda, kada joj je rod odrediv. Muškoga roda su, kada se on može odrediti, i sve mlađe povijesne srpske potvrde kojima raspolažemo, a takova je ta imenica i u današnjem srpskom standardnom jeziku.

\section{Leksem splav s gledišta tvorbe riječi}

S gledišta tvorbe riječi leksem splav bi se mogao tumačiti dvojako:

1. Leksem splav je odglagolna imenica izvedena iz splaviti. $\mathrm{Nu}$ u hrvatskom i drugim štokavskim jezicima splaviti nema znamenovanja iz kojega bi se ta imenica mogla izvesti. Niti jedno od (pod-)znamenovanja toga glagola koja su u Rječniku JAZU (XVI, 30-31) popisana ni izdaleka ne odgovara znamenovanju imenice splav. Između svih samo je jedno $(\operatorname{pod} b)$ : ,skinuti, odgrnuti”, preciznije 'skinuti s površine mlijeka'), koliko nam je poznato, ovjereno terenskim jezičnim spomenicima. Ono pod e) bi moglo biti istobitno s onim pod $d$ ), a ono pod d) bi moglo biti istobitno s glagolnom imenicom splavljenje u potvrdi $\mathrm{M}$. Radnića. To bi znamenovanje glagola splaviti bilo najstarije, i zemljopisno bi odgovaralo terenu na kojemu su grupirane stare potvrde imenice splav, ali je semantička veza nikakova.

Glagol plaviti u hrvatskom i inim štokavskim jezicima u principu nema znamenovanja 'prevoziti (= činiti ploviti) tekućom vodom', kakovo poznaju npr. češki ili ruski. Drugim riječima, gramatički subjekt štokavskoga plaviti nije agens, čovjek koji šalje objekt da vodom putuje, već naravna sila, sama voda.

Kada bi pak splaviti i imao takovu semantičku nijansu, mučno bi bilo odrediti semantičku nijansu prefiksa $s$ - u njemu.

Za ilustraciju: Kada bi se uzelo da je splav rusizam (što teorijski ne bi bilo nemoguće), problem bi se ončas razriješio. Ruski ima:

a) Glagol iz kojega se je ta imenica mogla izvesti, splavit'. Star je, polag Slovar'a russkogo jazyka XI-XVII vv. sa znamenovanjem 'otpravit' ili dostavit' splavom' posvjedočuje se od god. 1567. - 1571. (SRJ XI-XVII vv.: XXVII, 43a). 
b) Prefiks $s$ - s odgovarajućim semantičkim sadržajem. Ruski glagol splavi$t i$ od starine je dio paradigme koju čine, recimo, svezti (> svezt') znamenovanja 'vezja, dostavit' kuda-l., otvezti' (usp. SRJ XI-XVII vv.: XXIII, 107a) i snesti (> snest') znamenovanja 'otnesti, dostavit' (kuda-1.)' (usp. SRJ XI-XVII vv.: XXIII, 254a).

Samo što imenica splav u ruskom nema znamenovanja kao u hrvatskom i srpskom, i zato hrvatski i srpski splav ne mogu biti rusizam.

Najupotrebljiviji bi za etimologiziranje bio splaviti kakav se ukazuje u Njemačko-ilirskom slovaru I. Mažuranića i J. Užarevića (1842.), koji njemački leksem Floßholz tumače kao „splavljeno drvo”, a Floßplatz kao „mjesto za drva splavljena” (str. 169b); splaviti im je perfektiv od plaviti „flössen”. Nu takav (s) plaviti je kasan, a potvrda za nj je malo. Mogao bi biti bohemizam. Referira na vezivanje debala u splav radi njihova prevoženja riječnim putom. Ta je praksa (privredna grana u stvari), koliko nam je poznato, karakteristična za njemačke zemlje, a na hrvatski jezični prostor je prispjela eventualno u 19. st., ako i tada.

2. Leksem splav bi se, teorijski, mogao izvoditi iz leksema plav imeničnim prefiksom $s$-. Ponašanje i razredba imeničnoga $s$ - nije dobistreno; za primjer: leksem prud je u srpskom jeziku relativno nedavno dobio parazitski $s^{-}$, sprud (pa su ga takvoga Hrvati uzeli u svoj standard).

Ljubeznošću A. Gluhaka upućeni smo na članak slovenskoga etimologa M. Snoja (1989), kao i na njegov vlastiti (1993), u kojima razmišljaju da je $s$ - „stari prefiks koji znači 'kao"' (Gluhak 1993: 51). Gluhak u tom kontekstu i spominje imenicu splav (Gluhak 1993: 51), koja bi se onda imala tumačiti kao 'kao plav, kao lađa'. Ta je teorija zavodljiva i njome bi se pitanje etimologije imenice splav elegantno razriješilo. Nu prije izvođenja imenice splav iz imenice plav valja vidjeti što se može znati o imenici plav u arealu imenice splav.

Plav je leksem karakterističan za hrvatski jezik, preciznije za dubrovačku štokavštinu, dalmatinsku čakavštinu i, barem donekle, užehrvatsku čakavštinu. Izvan toga prostora Rječnik JAZU ga zabilježuje (X, 23 i 26) samo na nekoliko punktova: kod štokavca iz šibenskoga zaleđa P. Kneževića, kod srednjega Bosanca M. Divkovića (kao umanjenicu plavčica), kod Bačanina M. Radnića i kod Slavonca A. Tomikovića.

Uzme li se, spekulativno, da Radnić i Tomiković potječu iz onoga dijela hrvatskoga etničkoga korpusa koji se je na sjeveroistok hrvatskoga jezičnoga prostora, tj. u južnu Ugarsku, doselio s juga ili jugozapada uklanjajući se od Turaka, tada bi se moglo nagađati da je leksem plav onamo zašao seljenjem, i da relativno rane potvrde M. Radnića i ne tako rane A. Tomikovića zrcale situaci- 
ju u njihovu dijalektu. Hipoteza je u korijenu oslabljena činjenicom da je leksem plav između pisaca iz nutrine štokavskoga prostora posvjedočen samo kod srednjega Bosanca Divkovića (što bi mogao biti dalmatinski utjecaj) i, mnogo kasnije, kod Kninjanina Kneževića (valjalo bi ispitati bi li to bio dubrovački utjecaj).

Radnić se je leksemom plav, uključivši umanjenicu plavčica, u svojim dvjema knjigama, Pogargegne izpraznosti od sviyeta i Razmiscglagna pribogomiona od glivbavi Boxye (obje: 1683. C. Dragondelli. Rim. Prva je prijevod Dispregio della vanità del mondo G. B. Peruschija, druga prijevod Meditationi devotissime istoga autora) poslužio triput, jednom ga supostavivši s leksemom lađa:

- Oni koji bi se ubrodio u jednu plavčicu od gnjile nepečene, koja s mnogo stranā protiče, imao bi mala an razlog za imati ufanje od svoga života. [...]. Brođenje ovoga života jest burljivo, a duša brodi se u ovoj plavčici od zemlje našega tiela, [...]. (M. Radnić, Pogrđenje izpraznosti od svieta, 165a) $<$ tal. Colui che s'imbarcasse in una barchetta di creta non cotta...\& l'anima naviga in questa nave di terra del nostro corpo...

- Konji i svaka druga živina učine se lieni i budu nekorisni stojeći s mirom, i jošter plavi i lađe u pristaništima stojeći na mjestu prisuše se i izštete, a plaveći se uzdržavaju se, i u boju tko se većma miče, i rve se uzdanije, a oni koji stoji s mierom, susrite ga veće pogibili. (M. Radnić, Pogrđenje izpraznosti od svieta, 485b) $<$ tal. ...\& ancora le navi, \& le barche ne i porti stando ferme si guastano, \& rovinano...

Lađa se pak kod Radnića ukazuje nekih 21 put, kao hrvatska jednakovrijednica talijanske riječi nave. U rečenici sa str. $485 \mathrm{~b}$, u kojoj se skupa ukazuju plav i lađa, iz redoslijeda ishodi da hrvatska imenica plav odgovara talijanskoj nave, a hrvatska lađa talijanskoj barca. Bit će ipak da je lađa, kao i drugdje, prijevod nave, a da plav onda služi da bi se prevela barca. Potvrđuje to prva potvrda sa str. 165a, u kojoj plavčica = barchetta . U drugoj potvrdi s te stranice Radnić isti hrvatski leksem ponavlja da bi preveo talijanski nave, nedvojbeno po inerciji, umjesto hrvatskoga *lađa (nave svakako ne razumijeva deminutivizaciju). Prama tomu, plav je Radniću denotirala nešto kao 'mala lađa'.

Tomiković se u svojoj knjizi Xivot Petra Velikoga (1794. I. M. Divald. Osijek. Prijevod Vita di Pietro il Grande A. Catifora) leksemom plav poslužio dvaput:

- Od potribe je bilo da se svi podlože; i zaisto, s tolikom marljivostjom i žestinom počeo je ovi posao, da prije nego se je peta godina svršila, vidilo se je u Veronici četrdeset dobri ${ }_{h}$ brodovā bojni, trideset galijā, dvi stotine bregantinā (tanke plavi) i jedan veliki broj od korabljicā, osim četiri stotine lađā poveći na Dnieperu i tri stotine na Volgi. (A. Tomiković, Život Petra Velikoga, 77) < tal. 
...furono viste in Veroniza quaranta buone Navi da Guerra, trenta Galere, dugento Bregantini, e gran numero di Galeotte e Burlotti; oltre quattrocento Bregantini più grossi sul Boristene, e trecento Barche piatte sulla Volga.

- Veće je bio spravio (car) nike plavi povodnice po svojoj umi s kojima se je po moru obkoliti mogao grad i iz koji lašnje se je mogla staviti vojska na $\mathrm{su}_{\mathrm{h}} \mathrm{O}$. (A. Tomiković, Život Petra Velikoga, 271) < tal. Aveva già fatto fabbricare $\underline{Z a-}$ tte di sua invenzione...

Della Bella u svojem rječniku talijansku riječ bregantino glosira kao korabljica, tanka plav i polukorabljica (Della Bella: 148a), dakle stanovito je da je Tomiković leksem plav uzeo od Della Belle. Leme pak zatta Della Bella nema, umjesto nje je samo zattera, koju ne glosira kao *plav povodnica, već kao povodnica, drveni slog i povodnica drvena (Della Bella: 783a). Situacija je dakle složena: leksem povodnica je Tomiković brez dvojbe uzeo iz Della Belle, ali leksem plav može biti i vlastit njegov odredbeni pridatak leksemu povodnica.

Leksem plav pozna i slovenski jezik, i to u znamenovanju 'splav, plutva, povodnica'. Prvi put je posvjedočen u jednoj prirubnici u Bibliji J. Dalmatina (1584.), a posve je živ bio do druge polovice 19. st., kad ga je stao istiskivati splav. I formalno i sadržajno on bi mogao biti u vezi s hrvatskim i srpskim leksemom splav. Ali kako prostorišta tih dvaju leksema razdvaja velik pojas zemlje gdje plav nije posvjedočen, tj. srednjovjekovna Slavonija (hrvatska kajkavština i slavonska štokavština), oni ne mogu stojati u neposrednoj vezi jedan s drugim.

Iz rečenoga izlazi da su Radnić i Tomiković u svojem organskom dijalektu mogli imati leksem plav, ali da su dokazi za to više nego mršavi. Uzme li se još u obzir da u srpskom plav nije posvjedočen nikako, izvođenje imenice splav iz imenice plav može ostati samo u domeni spekulativnoga. Čini nam se, također, da je taj formacijski model morao biti operativan u većoj starini nego što je 18. st.

\section{Sinteza hrvatski + srpski}

Spoznaje o hrvatskom i srpskom leksemu splav možemo ovako sažeti:

a) Njegovo ishodište je negdje na sjeveroistoku hrvatskoga jezičnoga prostora, a čini se i negdje na sjeveroistoku srpskoga; koja se dva prostora preklapaju na tlu južne Ugarske (Bačka, Srijem), mađarskoga Podunavlja i istočne Slavonije.

b) U hrvatskom je ženskoga roda (deklinacija N splav, G splavi), a u srpskom muškoga (deklinacija N splav, G splava). 
c) U hrvatskom je u pravilu oznamenavao 'plutva, povodnica', a rijetko i 'lađa', dok je u srpskom oznamenavao isključivo 'plutva, povodnica'.

d) Teško je protumačiv rječotvornim sredstvima kako hrvatskoga, tako srpskoga jezika.

Što se vremena postanka leksema dotiče, ovisimo o a) hrvatskoj pismenoj predaji koja u južnoj Ugarskoj (sa Slavonijom) ne ide duboko u prošlost, i koju možemo slijediti brat bratu do kraja 17. i početka 18. st., ali praktično do 1730ih; b) o srpskoj pismenoj predaji, koja zamah dobiva stoprv 1780-ih. Odskače najstariji bačkohrvatski pisac M. Radnić (1683.), kod kojega splav ionako nije posvjedočen. Zato uz ono čim imamo, moramo zaklimati i onim što nemamo, tj. potencijalno je signifikantno da:

- Z. Orfelin u Pervim načatkima latinskago jazyka (1767. [D. Teodosio.] Mletci) latinsku imenicu ratis glosira na (slaveno)srpski kao plotz, floss i ladbja (str. 285), iz česa se može izvesti da nije poznavao leksema splav. To je svakako neobično, budući da je rođenjem Srijemac, Vukovarac.

- S. Vujanovski u Německoj grammatiki (1772. J. Kurzböck. Beč) njemačku imenicu Floß glosira (slaveno)srpskom plots (str. 87 i 368). Vujanovski je rođen u Brđanima kraj Hrvatske Kostajnice, pak se je manje čuditi da nije znao za splav.

Zato bi se moglo nagađati da je splav u srpskomu za nijansu mlađi negoli u hrvatskom. S druge strane, ako se je primanje iz hrvatskoga u srpski događalo negdje od 70-ih god. 18. st., posve je nedokučivo kako se je preraspodjela roda mogla odviti tako brzo i tako korjenito da, koliko znamo, ženski rod u srpskom nije niti jednom posvjedočen.

Ako je splav u vezi s imenicom plav 'lađa', tada je iz hrvatskoga morao prijeći u srpski, jer u srpskom plav nije posvjedočena. Pritom je morao, iz kojegagod uzroka, promijeniti rod.

\section{Potencijalna veza s problemom leksema splata}

Splata znamenuje nešto kao 'ponton', a gdjegdje i neke vrsti splav. Najstarija potvrda te riječi kojom raspolažemo jest iz prvoga izdanja Srpskoga rječnika V. S. Karadžića (1818.), dakle iz srpskoga jezika. Prva hrvatska kojom raspolažemo je 1856., iz napisa Bohinska dolina i Bledsko jezero stanovitoga M., objelodanjena u Nevenu, V, 338a. Splata je prama tomu postala negdje na srpskom jezičnom prostoru, da bi se druge polovice 19. st. proširila i hrvatskim. Potvrde dvojice pučkih narodopisaca Slavonaca J. Lovretića iz Otoka i L. Lukića iz 
Brodskoga Varoša svjedočile bi da se je do početka 20. st. leksem bio ponešto udomaćio u istočnoj Slavoniji.

Skok u osnovi leksema splata vidi leksem plata, kojemu je prelijepljen prefiks $s$ - $\mathrm{s}$ imenice splav (Skok: II, 678a i III, 312a). Leksem plata jednom izvodi iz hrv. i srp. korijena plat- (Skok: II, 678a-b), drugi put iz srlat. platta $>$ fr. plate $>$ stvnjem. pletta $>$ nvnjem. Platte (Skok: III, 312a).

Kako najstarije pojavnice imenice splav i imenice splata ne dijeli osobito velik vremenski razmak, ne bi brespametno bilo pomisliti i da se je $s$ - (prefiks?) $\mathrm{s}$ imenice splata prelijepio na leksem plav, dajući splav.

Leksem splata su u jednom času preuzeli i Turci, u obličju ispilata. Postoji li neki ambiciozniji etimološki rječnik turskoga, moglo bi se vidjeti kada se je preuzimanje dogodilo, iz česa bi se onda mogao izvući terminus ante quem stvaranja te imenice u srpskom.

Vrela:

navode se uz svaku potvrdu, radi uštede prostora ne ponavljaju se.

\section{Biografije:}

Hrvatski biografski leksikon: hbl.lzmk.hr

Srpski biografski rečnik: www.maticasrpska.org.rs/stariSajt/biografije

Matić, Tомо. 1940. Pjesme Antuna Kanižlića, Antuna Ivanošića i Matije Petra Katančića. Stari pisci hrvatski 26. JAZU. Zagreb.

\section{Literatura:}

GluhaK, Alemko. 1993. Kakva nam etimologija treba? Filologija 40. 41-64.

OreŠKović, Marko. 1978. Anonimi, pseudonimi, inicijali i šifre hrvatskih književnika i drugih kulturnih radnika u knjigama i periodičkim publikacijama. Građa za povijest književnosti hrvatske 32. 217-295.

SNOJ, MARKo. 1989. Sledi praslovanskega predloga $*_{S b-}$ 'podoben, enak, približen' v slovenščini. Slavistična revija 37/1-3. 151-158.

VIDAČIĆ, MARCEL. 1951. Pseudonimi, šifre i znakovi pisaca iz hrvatske književnosti. Građa za povijest književnosti hrvatske 21. 7-143.

Rječnici:

Della Bella, Ardelio. 1728. Dizionario italiano-latino-illirico. Cristoforo Zanne. Venezia.

Slovar' russkogo jazyka XI - XVII vv. 1975. - . Nauka. Moskva. 
GluhaK, Alemko. 1993. Hrvatski etimološki rječnik. August Cesarec. Zagreb. MaŽURANIĆ, IvAN; UžAREviĆ, JAKOv. 1842. Njemačko-ilirski slovar. Ljudevit Gaj. Zagreb.

Rečnik na bъlgarskija ezik: ibl.bas.bg/rbe/lang/bg

Rječnik hrvatskog ili srpskog jezika I-XXIII. 1880. - 1976. Ur. Daničić, Đuro i dr. JAZU. Zagreb.

SKOK, Petar. 1971. - 1974. Etimologijski rječnik hrvatskoga ili srpskoga jezika I-IV. JAZU. Zagreb.

\title{
Some Remarks on the Lexeme splav in Croatian and Serbian
}

\begin{abstract}
In an attempt at the elusive etymology of the Croatian and Serbian word splav, the author addresses some aspects of its origin, namely the issues of geographical distribution, semantics and gender of early attestations. The formation of the word is also discussed.

Ključne riječi: splav, povijest, tvorba riječi, etimologija.

Keywords: splav, history, word formation, etymology.
\end{abstract}


